\title{
Environmental Factors and Nomadic Education Goals' Achivement in Plateau State, Nigeria
}

\author{
Ogundele, Michael Olarewaju (Ph.D) \\ Department of Educational Foundations, University of Jos, Nigeria \\ michogun63@gmail.com \\ Oke, Tolutope Idowu. \\ Department of Educational Foundations, University of Jos, Nigeria \\ oketolu66@yahoo.com.
}

Hauwa'u Muhammed Mainoma

Department of Education Foundations, Faculty of Education, Nassarawa State University, Keffi

Doi:10.5901/jesr.2016.v6n1p224

\section{Abstract}

The study examined the influence of environmental factors on Nomadic education goals' achievement in Plateau State. A descriptive survey of correlation types was adopted for the study. Stratified random sampling technique was used to select respondents. The respondents comprised of Nomadic education headteachers, teachers, Assistant teacher's village heads, students. Also 500 respondents were selected from 63(37.1\%) out of 175 nomadic primary schools in Plateau State. Two research questions were asked and four research hypotheses were generated to guide the study. Environmental factors for nomadic education goals Achievement Questionnaire (EFNEGAQ) and structured interview were used for data collections. The instruments were validated by the experts in social sciences and education. Split-half reliability method was used to determine the level of reliability of the instrument. The result was correlated using Spearman Ranking Order statistics at .05 significance level. The index of 0.67 shows that the instrument was reliable. The research questions were answered using percentages while research hypotheses were tested using Pearson Product Moment Correlation statistics at 05 significance level. The findings of the study indicate that environmental factors like weather condition, cultural factors and school location have negative influence on the Nomadic education goals achievement in Plateau State. It was however recommended that adequate motivation should be given to both the teachers and students, that the nomadic education should integrate early childhood education into the system. The recommendations will enhance positive goals achievement of Nomadic Education in Plateau State.

Keywords: Environmental factors, Nomadic education and Goals Achievement.

\section{Introduction}

Education is a veritable tool for sustainable national development and societal transformation. It should be noted that Nigerian society agitated for equal educational opportunities for all and sundry without discrimination in terms of sex, tribe, race, religion and nationality, what the government want is quality assurance and control in the educational provision. Ogundele (2008) also regarded education as the process of training individual citizens to become responsible member of the society. The author however noted that any country that toyed with the educational provision for her citizens, such a country may not be ranked high among the developed nations of the world. However, for equal educational opportunities to be enhanced in Nigeria the Federal Republic of Nigeria had gulped billions of Naira in the provision of education for different groups of people that are marginalized in terms of formal education.

Ojuekaiye (2014) identified the marginalized people as nomadic Fulani's, Fishermen in the Riverine areas and adults that did not have opportunities for formal education at their youthful period. In 1986, Jibril Aminu who was then the Minister of Education launched Nomadic education programme for the Nomadic Fulani's. According to Ezeomah (2004), Nomads are members of community that moves with their animals from one place to the other. The author stated that Fulanis in Northern Nigeria are good examples. The author also described Nomads as migrant ethnic population that 
they have common traits and occupations. Nomadic Fulanis are pastoralists who does not have stable place. They move about different regions to search for green pasture for their animals.

Akinpelu (1993) also defined Nomadism as a type of existence that is characterized by the absence of a fixed domicile and abode. The author also identified six nomadic groups in Nigeria as the Fulanis, the Shuwa, Buduman, kwayan, Baduwi and the Fishermen. Yet the Federal Republic of Nigeria (2000) observed that the Nomads in Nigeria have socio-economic crisis in terms of their educational system. The crises however bring about the need to introduce Nomadic education. The National Council for Nomadic Education (NCNE) was established by the government in a bid to examine the strategies for educating the Nomadic migrants in Nigeria. The Federal Republic of Nigeria (2000) also reaffirmed article 26 of United Nations 1984 universal declaration on human right that everyone has the right to education and the education is a birth right that individual should enjoy as a member of the society based on that declaration the government of Nigeria had committed itself to literacy enhancement of the Fulanis. The Federal Republic of Nigeria also stressed that education is the birth right of every child and that the education should be brought close to the environment of the child. Ibrahim (2005) also examine the reasons why Nomads should be provided with quality education as follows to raise the standard of living of the Nomads, to harness their potentials and to bridge the literacy gaps between the nomads and the rest of the society.

It should be noted that the Federal Republic of Nigeria is interested in the educational provision for the Nomadics Fulanis. They had established various Nomadic schools so as to be educated. Yet the nomadic Fulanis are used to living in a temporary places, they are interested following their cattles about how then can the necessary educational opportunities be provided for the Nomads. Also as billions of Naira are gulped to the programme. The programme is therefore militated against by the environmental factors. Ogundele (2004) environment as the combination of both physical and social resources that are found in man environment. The author however described physical environment as those natural or manmade resources that are in man surroundings like vegetation, water, climate, soil, relief factor needed climate, rich vegetation, water, while the social environment embraces those peer groups, family parents and the interaction with their cattle. According to Osukoya and Amad (2002) stated that only six percent of the children in Mozat Ropp nomadic schools are Fulani children that rotate herding and schooling

However, the rationale for this study is that despite all the efforts made by the Federal republic of Nigeria in educating the Nomads so as to make them compatible with the global dynamic changes, will the available environmental factors encourage Nomadic education goals achievement? How then can environmental factors be modified to enhance educational provisions for the Nomads especially in Plateau State.?

\section{Statement of Problem}

Over the years, Nomadic education had become one of the systems that attracted the global and international attention. It should be noted that the educational provisions for the nomads is a complex one due to their unstable and nonresidential nature of their living. The problem of investigation is to find out strategies for integrating Nomadic education despite, the available environmental factors that will enhance effective goals achievement of Nomadic education especially in Plateau State, Nigeria.

\section{Purpose of the Study}

This study assessed the influence of the environmental factors on Nomadic education goals achievement in Plateau State, Nigeria. The study specifically examined the available environmental factors for nomadic education programme in Plateau State

- The indicators of Nomadic education goals' achievement in Plateau State.

- The influence of the environmental factors for enhancing Nomadic education goals achievement.

- The strategies for modifying the available environmental factors for achieving goals of Nomadic education in Plateau State.

\section{Research Questions}

The following research questions were asked to guide the study;

RQ1: what are the available environmental factors that really influence Nomadic education programme in Plateau State? 
RQ2: what are the modifying strategies for enhancing effective goals achievement of Nomadic education programme in Plateau State?

\section{Research Hypotheses}

The following research hypotheses were also formulated for the study.

$\mathrm{Ho}_{1}$ : There is no significant relationship between environmental factors and Nomadic education goals achievement in Plateau State.

$\mathrm{H}_{2}$ : There is no significant relationship between physical environmental factors and Nomadic education goals achievement in Plateau State.

$\mathrm{H}_{0}$ : There is no significant relationship between social environmental factors and Nomadic education goals achievement in Plateau State.

Ho4: There is no significant relationship between environmental factors modifications and Nomadic education goals achievement in Plateau State.

\section{Methodology}

The research design for this study was a descriptive survey of correlation type. The researchers made thorough investigations into the availability of physical and social environmental factors and their influence on the Nomadic educational goals achievement variables like equal educational opportunities arousing their interest on formal education and enhancing conducive standard of living for the Nomads especially in Plateau State. The population of the respondents comprised of the village heads, head teachers, teachers and the literate students. Stratified Random Sampling technique was used to select 50 Nomadic Education centres in the state and total numbers of 500 respondents were selected for the study. Environmental factors for Nomadic Education Goals Achievement Questionnaire (EFNEGAQ) and structured interview used to collect relevant data. The instruments were validated by the experts of environmental management. Spilt-half reliability method was used to test reliability coefficient of (EFNEGAQ) instrument. The data collected was subjected to Spearman's Ranking Order Statistics. The Index of 0.67 indicated that the instrument was reliable for use. The research questions were answered using descriptive statistics like percentages, while all the research hypotheses were tested using Pearson product moment correlation statistics at) .05 significance level. The choice of statistical method was made because the study involved the use of research question to be answered and there are correlation variables involved.

\section{Results}

The result of data collected were analyzed below

\subsection{Research Question 1}

What are the environmental factors that really influenced Nomadic education goal achievement in Plateau State?

Table 1: Environmental Factors that influence nomadic education goals achievement in plateau State.

\begin{tabular}{|c|c|c|c|c|c|}
\hline \multirow[b]{2}{*}{ S/No } & \multirow{2}{*}{ Statement } & \multicolumn{2}{|c|}{ Agreed } & \multicolumn{2}{|c|}{ Disagreed } \\
\hline & & No & $\%$ & No & $\%$ \\
\hline 1. & Excessive rainfall debarred the nomads from attending schools & 362 & 72.4 & 138 & 27.6 \\
\hline 2. & Parental economic interest on search for grazing for animals. Disturbed Nomadic education & 320 & 64 & 180 & 36 \\
\hline 3. & Extreme coldness of weather discourage Nomadic Education & 264 & 52.8 & 236 & 47.2 \\
\hline 4. & Environmental insecurity create problem for Nomadic education & 361 & 72.2 & 139 & 27.8 \\
\hline 5. & Continual searching for green pastures or grazing create problem & 373 & 74.6 & 127 & 25.4 \\
\hline 6. & Inadequate exposure to western education is affecting Nomads & 368 & 53.6 & 132 & 46.4 \\
\hline 7. & Communication blockage affect Nomadic education & 350 & 72 & 140 & 28 \\
\hline 8. & Poor infrastructural development of the environment & 295 & 59 & 205 & 41 \\
\hline 9. & Parental conservative attitude to western education & 396 & 79.2 & 104 & 20.8 \\
\hline 10. & Low interaction with the educated elites in the society & 284 & 56.8 & 216 & 43.2 \\
\hline
\end{tabular}


Table 1 show that 500 respondents answered the research question which demanded for the environmental factors that influence nomadic education programme especially in Plateau State, Nigeria. However, $72.4 \%$ of the respondents agreed that excessive rainfall debarred the Nomads children to attend schools, $64 \%$ of the respondents also agreed that parental economic interest also affect nomadic education programme. Furthermore, 52.8\% also agreed that extreme coldness of weather affect the Nomadic children from attending the schools at early stage of their schooling. Also, $72.2 \%$ of the respondents said that high rate of environmental insecurity constitute problem for effective implementation of Nomadic education. This result is in line with Osukoya and Ahmed (2002) which stated that out of 100 nomadic herdsmen children that attend nomadic primary schools in Plateaus State only 10 of them are Fulani children. The authors also in line with $74.6 \%$ also agreed that continual search for pasture or grazing field for the animals disallowed the nomad to attend the established schools. Also, $53.6 \%$ of the respondents also agreed that failure of the nomadic education programme was due to inadequate exposure to western education.

No wonder that Olufemi (2011) stated that due to the fact that the nomadic cattle rearers and fishermen are marginalized because of their nature of life style and lack of permanent settlement they did not have proper enlightenment on the need to acquire western education and inadequate exposure to western education programme. Furthermore, $72 \%$ of the respondents also agreed that the communication blockage is one of the social environmental factors that influence effective implementation of National education Programme in Plateaus State.

The result is in line with the opinion of Nazir and Pedretti (2014) which stated that the cattle rearers speak fufulde and other languages while the Nomadic education teachers cannot speak the language, they can only speak English language and the cattle rearers cannot speak English language. The means of communication therefore become a problem for effective learning. Poor infrastructural facilities in their settlements was also agreed upon by $59 \%$ of the respondents, while 79.25 agreed that the parents are just too conservative to allow effective schooling for their children and $56.8 \%$ of the respondents also agreed that because of their unpermanent life styles they are marginalized and they have low interaction with the educated elites in the state. Low interaction affects nomadic education.

\subsection{Research Question 2}

How can the environmental factors be modified towards enhancing effective goals achievement of Nomadic education in Plateau State?

Table 2: Environmental factors modification for enhancing effective goals achievement of nomadic education programmes in Plateau State.

\begin{tabular}{llcccc}
\hline & & \multicolumn{3}{c}{ Agreed } & \multicolumn{3}{c}{ Disagreed } \\
S/No & Statement & No & $\%$ & No & $\%$ \\
\hline 1. & Provision of adequate environmental security for the nomads. & 374 & 74.8 & 126 & 25.2 \\
2. & Adequate teachers and students motivation should be enhanced for the Nomads. & 349 & 69.8 & 151 & 30.2 \\
3. & Settling the nomads in a conducive environment with necessary infrastructure. & 407 & 81.4 & 093 & 18.6 \\
4. & Adequate encouragement should be given to the nomads by patronizing their products. & 266 & 53.2 & 234 & 46.8 \\
5. & The teachers should encourage effective time management to allow the nomads by & 269 & 53.8 & 231 & 46.2 \\
& patronizing their products after school hour. & & & & \\
6. & Setting up environmental modification committee for nomads & 263 & 52.6 & 237 & 48.4 \\
7. & Nomads should be involved in the decisions relating to nomadic education. & 394 & 78.8 & 104 & 21.2 \\
8. & The government and non-governmental agencies should assist in the provision of grazing & 390 & 78 & 110 & 22 \\
& camp for the Nomads. & & & & \\
9. & Joint programme that will enhance interpersonal relationship between the educated and & 271 & 54.2 & 229 & 45.8 \\
& nomads groups & 348 & 69.6 & 152 & 30.4 \\
10. & Learners support services should be provided for nomads to make a rational choice & & & & \\
& between education and pasturism
\end{tabular}

Table 2 also answered the research questions which deal with the strategies for modifying environmental factors towards enhancing effective implementation of Nomadic education programmes, in order to achieve Nomadic education goals. However, $74.8 \%$ agreed on the need to provide adequate environmental security for the nomads. The result is in line with the opinion of Bruyere, Wesson and Teel (2012) which believed that when environment are secured the parents will have rest of mind in sending their children to the schools. Ogundele and Afolabi (2010) opined that when environment is secured, it will reduce high rate of absenteeism, dropped out rate and the effective internal efficiency will be enhanced in 
Nigerian educational system. Also 69.85 of the respondents agreed that if both the Nomadic education teachers are adequately motivated they will be interested in the implementation of Nomadic education programme to enhance effective goals achievement especially in Plateau State. Furthermore, $81.4 \%$ agreed on the need to establish permanent settlement for the Nomadic herdsmen and fishermen so that they will give them proper education. The result was in line with Conde and Sanchez (2010) which also agreed that the Nomadic herdsmen should be compared and provided with all the necessary facilities, landscaping and green land for their animals to the extent that they will not have the mind of wandering for animals grazing, for that reason they will be provided with the required education and nomadic education garb will be achieved. Also $53.2 \%$ of the respondents agreed on the facts that when the nomadic herdsmen and fishermen products are patronized directly they will not be wandering about. When they are settled they will be able to be accessed with the required education. Programme. Furthermore, 53.8\% agreed that the teachers should have time management technique to extent that when it is the time for them to follow their herds they should allow them to go.

The result was supported by Digdem (2010) which called for effective time management technique that will enable individuals to do whatever he wants to do at the right time. The nomadic education should be provided at the right time when their interest is yet to be diverted to pasturalism. Also the need to set up environmental management committee was agreed upon by $52.6 \%$ of the respondents and $78.8 \%$ also agreed that the Nomadic herdsmen should be involved in the decisions that relate to their problems. Furthermore, $78 \%$ of the respondents agreed that provision of grazing camps for the nomads herdsmen and fishermen should be a joint responsibility of the government, non-governmental agencies and well-meaning Nigerians in order to complement governmental efforts in educational provision for the nomads. Finally, learners support services should be provided in Nomadic education schools was agreed upon by $69.6 \%$ of the respondents. The result was also supported by Ogundele (2014) work which identified the necessary learners' support services that could be integrated into the school system. The identified learners' support services are recreational, transportation, utility, counselling, welfare and library information services. The author noted the provision of learners support services will go a long way in enhancing goals achievements of Nigerian educational system and nomadic education programme is not excluded.

\section{Hypotheses Testing}

The null hypotheses generated were tested using Pearson Product Moment Correlation statistics at .05 significance level.

$\mathrm{H}_{01}$ : There is no significant relationship between environmental factors and nomadic education goals achievement in Plateau State.

Table 3: Environmental factors and nomadic education goals achievement in Plateau State

\begin{tabular}{|c|c|c|c|c|c|c|c|}
\hline Variables & No & $\bar{x}$ & $\mathrm{Sd}$ & Df & $\begin{array}{l}\text { Calculated } \\
\text { r-value }\end{array}$ & $\begin{array}{l}\text { Critical } \\
\text { r-value }\end{array}$ & Decision \\
\hline $\begin{array}{l}\text { Environmental factors } \\
\text { Nomadic education goals achievement }\end{array}$ & $\begin{array}{l}500 \\
500\end{array}$ & $\begin{array}{l}73.62 \\
38.29\end{array}$ & $\begin{array}{l}36.24 \\
46.32\end{array}$ & 499 & .62 & .196 & $\begin{array}{c}\mathrm{H} 01 \\
\text { Rejected }\end{array}$ \\
\hline
\end{tabular}

Table 3 Shows the correlation analyzed of environmental factors and nomadic education goals achievement in plateau state. The result indicates that the calculated r-value of .62 is greater than the critical r-value of .196 at the degree of freedom of 499 and tested at .05 significance level. Hence there is no significant relationship between environmental factors and however nomadic education goals achievement is however rejected. The results however indicate that the environmental factors like water, climate, vegetation, soil, and availability of people have high positive correlation, significant with nomadic education goals achievement. It should be noted therefore that in Plateau state, the environmental factors aid nomadic education goals achievement in the state. The result is however supported by Ogundele, Bada and Bello (2013) which opined that environmental variables dictate the traits, personality and whatever individuals become in later life. The study was also in line with findings Olaniyan (2010), Ogundele and Afolabi (2010) and Ogundele (2004), which stated that man need to modify the available factors to make them suitable for conducive livings. However, in Plateau State the federal and state government provided conducive environment for effective teaching and learning of nomads which aid effective goals achievement of nomadic education.

$\mathrm{HO}_{2}$ : There is no significant relationship between physical environment and nomadic education goals achievement in Plateau State. 
Table 4: Physical environmental factors and nomadic education goals achievement in Plateau State.

\begin{tabular}{lccccccc}
\hline Variables & No & $\overline{\mathrm{x}}$ & Sd & Df & $\begin{array}{c}\text { Calculated } \\
\text { r-value }\end{array}$ & $\begin{array}{c}\text { Critical } \\
\text { r-value }\end{array}$ & Decision \\
\hline Physical environment & 500 & 62.42 & 33.78 & \multirow{2}{*}{499} & .67 & .196 & $\mathrm{HO}_{2}$ rejected \\
Nomadic Education Goals achievement & 500 & 38.29 & 46.32 & & .67 & & \\
\hline
\end{tabular}

Table 4 Shows that the calculated r-value of 0.67 is greater than the critical r-value of .196 at the degree of freedom of 499 and tested at 0.05 significance level. Hence the null hypothesis which stated that there is no significant relationship between physical environment and Nomadic education goals achievement is however rejected. The result indicates that the availability of physical environment like conducive climate, vegetation cover for pastural activities and water for the animals have significant impacts on the teaching-learning processes in the nomadic education. The result is therefore supported by Onomake and Ajinwo (2012) which stated that physical environment produce many environmental resources which are improvised to aid effective teaching in the schools. However, this is applicable to Nomadic education.

$\mathrm{H}_{3}$ : There is no significant relationship between social environmental factors and nomadic education goals achievement in Plateau State.

Table 5: Social environmental factors and nomadic education goals achievement in Plateau State.

\begin{tabular}{|c|c|c|c|c|c|c|c|}
\hline Variables & No & $\bar{x}$ & $\mathrm{Sd}$ & Df & $\begin{array}{c}\text { Calculated } \\
\text { r-value }\end{array}$ & $\begin{array}{l}\text { Critical } \\
\text { r-value }\end{array}$ & Decision \\
\hline Social environmental factors & 500 & $\begin{array}{l}56.24 \\
3829\end{array}$ & 28.77 & 499 & .58 & 196 & $\begin{array}{c}\mathrm{HO}_{3} \\
\text { Reiected }\end{array}$ \\
\hline
\end{tabular}

Table 5 shows that the calculated r-value of 0.58 is greater than the critical r-value of 0.196 at degree of freedom of 499 and tested at 0.05 significance level. Hence the null hypothesis which stated that there is no significant relationship between social environment and nomadic education goals achievement is however rejected. The result is however indicates that high positive significant relationship exist between the social environmental factors and goals achievement of nomadic education. This is because primary schools are endowed with well qualified teachers society peer group government and culture. However the social environmental factors available encourage effective dissemination of effective teaching and learning process that like give adequate educational opportunities for the nomads.

The result was negated by the work of Adeyemi (2013) that observed that cultural factor which encourage pasturalism at early stage of Nomads have baneful effects on the nomadic educational provision. The author went further to say that there is nothing to do or say or teach the nomads that can delay or tie down a nomad to follow their herds when it is about 1.00 o clock in the afternoon. In Plateau State, the government and other stakeholders had really encouraged Nomadic education programmes through motivation of the nomadic teachers, establishing nomadic primary schools in every nook and corners of Plateau State and inviting them for meetings which contribute to the creation of rights awareness and types of opportunities deprived in the society.

Ho4: There is no significant relationship between environmental factors modifications and nomadic education goals achievement in Plateau State.

Table 6: environmental factors modification and Nomadic Education goals achievement in Plateau State.

\begin{tabular}{lccccccc}
\hline Variables & No & $\overline{\mathrm{x}}$ & Sd & Df & $\begin{array}{c}\text { Calculated } \\
\text { r-value }\end{array}$ & $\begin{array}{c}\text { Critical } \\
\text { r-value }\end{array}$ & Decision \\
\hline Environmental factors modification & 500 & 65.21 & 38.72 & 499 & 0.61 & 0.196 & $\begin{array}{c}\mathrm{H}_{4} \\
\text { Rejected }\end{array}$ \\
Nomadic education goals achievement & 500 & 38.29 & 46.32 & & & &
\end{tabular}

Table 6 shows that the calculated r-value of 0.61 is greater than the critical r-value of 0.196 at the degree of freedom of 499 and tested at 0.05 significance level. However, the null hypothesis which stated that there is no significant relationship between environmental factors modification and nomadic education goals achievement is however rejected. It indicates that all efforts put in place for the environmental modification for effective settlement of nomads and make 
them settled in a place is fruitful. The result also aid effective provision of education for the nomads in Plateaus State.

The result was supported by Ayodele (2010) who examined the strategies for modifying school environment to be suitable for effective teaching-learning processes. The strategies identified are teacher's motivation, building of good classrooms, provision of educational facilities, interpersonal relations using learner's centredness approach for teaching, maintenance of positive community-school relation, involvement of stakeholders in education, provision physical utility such as light, water, and access roads for the rural schools. However, in Plateau State the government provided all the strategies by institutions can be built for the purpose of educational provision to the nomads. The environmental modification strategies however go in long way to assist the nomads to have interest in education and the numbers of the pupils in the nomadic schools are increasing. Also Ogundele and Afolabi (2010) noted that any schools located in the environmental degradated areas such as flooded, erosion, thick forest may not have enough students and parental patronage.

However this finding negates the current study because the nomadic education institutions are built in line with the cultural background of nomads. Since nomads do search for green pasture for their herds. The educational practitions therefore site the nomadic primary schools where there are green pastures that as they are in the school their herds will be feeding on the vegetation around the school. The same thing is applicable to those nomads near the riverine areas. Their schools were established in areas liable to flooding for the purpose of encouraging them to acquire some basic education that will help them better in their economic activities and provide them with knowledge of having conducive standard of living. This is so in Plateau State.

\section{Conclusion}

Based on the result of data collected and the analysis made, the result revealed that environmental factors have positive significant relationship with the nomadic education goals achievement in Plateau State. It could be concluded that the education stakeholders, like government, communities and the teachers put in efforts towards encouraging educational provision for the nomads. It should be noted that there is the need for and that the nomadic schools environment to be modified suitable for the nomads through citing of schools in areas where adequate grazing will be provided for their herds why the pupils receive education in the primary schools provided within the same environment. The efforts therefore and effective nomadic education goals achievement especially in Plateau State.

\section{Recommendations}

Based on the data analysis, discussion made and the conclusion the following recommendations were proffered.

Setting up environmental management committee for the nomads: Plateau State Government should set up an environmental monitoring committee to see that the nomads who are the herdsmen and those that are fishermen are living together in peace with farmers in the state. Their peaceful coexistence with the members of the society will aid effective implementation of nomadic education policy and such implementation will aid effective goals achievement of nomadic education.

Enforcement of environmental assessment laws: Enforcement of environmental assessment laws to aid effective bio diversification of the environmental variables like control of erosion, floods, planting of trees and grasses, effective sanitary controls, involvement of the nomads in the monitoring and security of environment. When nomads are involved in the environmental assessment laws such involvement will aid environmental literacy and adaptability to the environmental changes. Such assessment laws will try to enforce nomadic education programme in Plateau State.

Early childhood education should be integrated into Nomadic Education programme: Integration of early childhood education to nomadic education programme in the state. It is important to note that for effective goals achievement of nomadic education to be enhanced, the nomads children should be sent to school at early years because it is better to train the child than repair an adult. Exposing the herdsmen and fishermen children to western education at early stage of their childhood will go a long way in enhancing effective goals achievement of nomadic education in Plateau State.

Provision of learners support services for the Nomadic schools: Learners support services like accommodation, feedings, recreational facilities, hostels counselling services and instructional services. The services provided will enable the nomadic Fulanis to be interested in staying in the schools rather than following their herds in the state.

Nomadic education capacity building should be introduced for nomadic education teachers: Seminars, workshops and conferences on environmental modification for nomadic education goals achievement should be organized in Plateau state. The organization conference on environmental literacy and adaptability for the Nomadic Fulanis and the 
stakeholders on nomadic education policy implementation towards goals achievement will aid effective goals achievement of nomadic education in Plateau State.

Establishment of nomadic comp for nomads: Introduction of nomadic camps for the nomadic herdsmen and fishermen: The government, the stakeholders and well meaning individuals should help in the provision of all the necessary infrastructural facilities like restaurants, schools, grazing field for their herds and abattoir market. When they are in the camp nomadic education programme will be effective goals achievement of nomadic education in Plateau State.

National association of nomadic education should be formed: The association formed should be charged with the responsibilities of research, conference, counselling and preferring adequate recommendations that will aid effective goals achievement especially in Plateaus State and Nigeria in general.

Nomadic education should be planned by the nomadic Fulanis themselves. Any decisions relating to Nomadic education planning should involve the Nomadic herdsmen and fishermen with the supervision or the teachers. For the approach will make nomadic education go goals realisable.

\section{References}

Adeyemi, O. D. (2013). Schools environmental factors and students' academic performance of private secondary schools in llorin-South Local Government Area. Ilorin researcher 5(2), 55-61.

Akinpelu, J. A (1993). Community involvement, environmental modification and goals achievement of primary education in Niger State. International Journal of Research 5(2), 48-52.

Ayodele, A. A. (2010). Environmental variability and students academic performance of secondary schools in Kwara State. Unpublished PGDE project of National Teachers' Institute, Kaduna Nigeria.

Bruyere, B. L., Wesson, M. \& Teel, T. (2012). Incorporating environmental education into urban after school programme in New York. International Journal of environmental and Science education 9(3), 265-283.

Digdem, M. 92010). Time management and academic performance of master level students in turkey. International Journal of Business and Management Studies 2(1), 25-28.

Conde, M. C. \& Sanchex, J. S. (2010). School Curriculum and environmental education: A school environmental experience. International Journal of environmental and science education 59(4), 477-494.

Ezeomah, C. (2004). Nomadic Education in Nigeria. Jos: University Press.

Federal Republic of Nigeria (2000). National Policy on environmental studies. Abuja: Ministry of environment.

Ibrahim, B. A. (2005). Teachers' variables and academic performance of secondary schools students in Kogi State. Unpublished Ph.D Thesis, University of Illorin. Illorin Nigeria.

Nazir, J \& Pedretti, E. (2014). Tension and opportunities: A baseline study of teachers view of environmental education. International Journal of Environmental and Science Education 9(3), 265-283.

Kopnina, H. (2014). Future scenarios and global environmental education. Journal of environmental education 45(4), 217-231. http://www.tandfonline.com/ujcee

Ogundele, M. O. (2008). Funding teachers' job satisfaction and students' academic performance of private secondary schools in Kwara State Nigeria. Unpublished Ph.D Thesis. University of Ilorin Ilorin Nigeria.

Ogundele, M. O. (2004). Environmental factors and teachers' job performance of secondary schools in Kwara State. Unpublished Ph.D project proposal University of Ilorin.

Ogundele, M. O. (2014). Learners' Support services and Nigerian distance education goals achievement in African Journal of Education research and development 6(1), 21-27.

Ogundele, M. O. \& Afolabi, S. O. (2010). Climate change and internal efficiency of secondary schools in Kwara State. Journal of National Association of Educational Administration and Planning 9(2), 140-153.

Ojuekaiye, F.F. (2014). Intervention of Adult Education in the Nomadic Education in Yagba Local Government Area Kogi State. Unpublished B.Ed project University of Jos.

Olaniyan, M. A. (2010). Physical resource allocation and internal efficiency of Nigerian distance Education. Unpublished PGDE project of National teachers Institute Kaduna.

Olufemi, R. A. (2011). Role of Nomadic education in achieving Millennium Development Goals in Sub Sahara Africa. International Journal of Tropical Agriculture 59(1), 58-64.

Omonake, O. R. \& Ajinwo, J. A. (2012) Safe learning environment: A Growing concern in secondary schools in River State. Journal of Vocational Education and Technology (1\&2), 161-172.

Osukoya, I. O \& Ahmed, C. A. (2002) Factors militating against Nomadic education programmes in Nigeria. Journal of Clinical and Counselling Psychology 8(1), 25-42. 